\title{
Pengembangan Nilai-Nilai Kearifan Lokal Suku Sasak Sebagai Suplemen Materi Ajar Pada Mata Pelajaran IPS SMP Negeri 4 Jerowaru Kabupaten Lombok Timur
}

\author{
Yunan Heri $^{1 *}$, I Putu Sriartha ${ }^{1}$, I Nengah Suastika ${ }^{1}$ \\ 1Universitas Pendidikan Ganesha, Indonesia \\ *e-mail: yunanheri0105@gmail.com
}

Article history: Received 08 July 2021; Accepted 14 July 2021; Available online 31 August 2021

\begin{abstract}
Abstrak
Penelitian ini dilakukan di SMP Negeri 4 Jerowaru dan bertujuan untuk (1) mengetahui nilai-nilai sosial dan budaya masyarakat suku Sasak yang dapat dimanfaatkan sebagai suplemen materi ajar IPS. (2) mengetahui keterkaitan nilai kearifan lokal masyarakat suku Sasak dengan tujuan dan ruang lingkup materi IPS. (3) nilai-nilai sosial dan budaya yang terdapat dalam kearifan lokal masyarakat suku Sasak dikembangkan sebagai suplemen bahan ajar dalam pembelajaran IPS. Penelitian ini menggunakan penelitian pengembangan dan menggunakan teknik analisis interaktif untuk rumusan masalah pertama dan menggunakan teknik analisis deskriptif komparatif untuk rumusan masalah kedua, serta menggunakan teknik gregory dan konversi tingkat pencapaian dengan skala 5 untuk rumusan masalah ketiga, yaitu define, design dan develop. Subjek dalam penelitian ini adalah informan inti dan siswa. Hasil penelitian ini menunjukkan bahwa: (1) wujud dari nilai sosial dan budaya yang terkandung di dalam kearifan lokal suku Sasak yaitu besiru, begawe, besentulak, gendang beleq dan presean; (2) keterkaitan nilai kearifan lokal terhadap materi IPS SMP, seperti kearifan lokal besiru berkaitan dengan materi bentuk-bentuk interaksi sosial; begawe berkaitan dengan materi bentuk-bentuk interaksi sosial dan pranata sosial; besentulak berkaitan dengan materi bentuk-bentuk interaksi sosial dan pranata sosial; (3) pengembangan uji kelayakan suplemen materi ajar IPS menujukan hasil 86,82 $\%$ katagori baik sedikit revisi, dan uji kepraktisan bahan ajar oleh siswa di kelas VIII 1 dengan hasil 88,32 \% katagori baik sedikit revisi, serta sampai pada bentuk akhir produk bahan ajar IPS tersebut jadi.
\end{abstract}

\begin{abstract}
This research was conducted at SMP Negeri 4 Jerowaru and aimed to (1) find out the social and cultural values of the Sasak people that can be used as a supplement to social studies teaching materials. (2) knowing the relevance of the value of local wisdom of the Sasak people with the objectives and scope of social studies material. (3) the social and cultural values contained in the local wisdom of the Sasak people are developed as a supplement to teaching materials in social studies learning. This study uses development research and uses interactive analysis techniques for the formulation of the first problem and uses comparative descriptive analysis techniques for the formulation of the second problem, and uses the Gregory technique and the conversion level of achievement with a scale of 5 for the third problem formulation, namely define, design and develop. The subjects in this study were core informants and students. The results of this study indicate that: (1) the manifestation of social
\end{abstract}

Kata Kunci:

Nilai-Nilai Kearifan Lokal; Sumber Belajar IPS; Pendidikan IPS
Keywords:

Local Wisdom Values; Learning Resources For Social Science; Social Studies Education 
and cultural values contained in the local wisdom of the Sasak tribe, namely besiru, begawe, besentulak, gendang beleq, and presean; (2) the relevance of the value of local wisdom to the social studies material for junior high schools, such as the local wisdom of besiru related to the material of forms of social interaction; begawe related to the material forms of social interaction and social institutions; related to the material forms of social interaction and social institutions; (3) the development of the feasibility test for social studies teaching material supplements showed results of $86.82 \%$ in the good category with slight revisions, and the practicality test of teaching materials by students in class VIII 1 with the results of $88.32 \%$ in the good category with slight revisions, and arrived at the final form of the material product teach IPS.

\section{Pendahuluan}

Tujuan pendidikan yang ideal bagi bangsa Indonesia telah dirumuskan dalam UndangUndang Nomor 20 Tahun 2003 tentang Sistem Pendidikan Nasional yaitu bahwa pendidikan adalah usaha sadar dan terencana untuk mewujudkan suasana belajar dan proses pembelajaran agar peserta didik secara aktif mengembangkan potensi dirinya untuk memiliki kekuatan spiritual keagamaan, pengendalian diri, kepribadian, kecerdasan, akhlak mulai, serta keterampilan yang diperlukan dirinya, masyarakat, bangsa dan negara.

Dalam hal ini berarti bahwa posisi pendidikan adalah sebagai bagian dari jaringan praktik kehidupan sosial budaya yang kompleks dari suatu masyarakat. Oleh karena itu, proses pendidikan tidak hanya harus dibatasi pada praktik-praktik pembelajaran di lembaga pendidikan. Akan tetapi proses pendidikan di sekolah mestinya dapat dijadikan sebagai media dalam proses pengenalan maupun penanaman budaya, norma, nilai-nilai yang ada di masyarakat yang nantinya mereka dapat mengimplementasikannya di dalam masyarakat.

Proses mempersiapkan peserta didik yang memiliki karakter dan peka terhadap kondisi sosial harus dilakukan. Oleh karena itu, peserta didik senantiasa dibekali dengan pengetahuan, nilai-nilai moral dan membiasakan mereka agar selalu berpikir kritis dan kreatif dalam mengambil tindakan ataupun keputusan. Untuk mewujudkan harapan itu maka sekolah sebagai lembaga formal senantiasa mengadakan pembinaan yang berkenaan dengan pendidikan masalahmasalah sosial melalui program pendidikan IPS. Selain itu, Rachmah (2014) mengatakan bahwa terkait dengan perubahan di masyarakat, pendidikan IPS mutlak diperlukan. Melalui pendidikan IPS di sekolah, siswa diharapkan dapat memiliki pengetahuan dan wawasan tentang konsep dasar ilmu sosial dan humaniora, memiliki kepekaan dan kesadaran terhadap masalah sosial di lingkungannya, dan mampu memecahkan masalah sosial secara baik, yang pada akhirnya mereka dapat menjadi warga negara yang baik dan bertanggungjawab.

Pendidikan IPS di sekolah merupakan mata pelajaran atau bidang kajian yang mendudukan konsep dasar berbagai ilmu sosial yang disusun melalui pendekatan dan pertimbangan psikologis serta kebermaknaannya bagi siswa dalam kehidupannya melalui dari tingkat SD sampai SMP/MTs. IPS mengkaji seperangkat peristiwa, fakta, konsep dan generalisasi yang berkaitan dengan isu sosial (Lasmawan, 2010). Melalui mata pelajaran IPS, peserta didik diarahkan untuk dapat menjadi warga negara Indonesia yang demokratis, dan bertanggung jawab, serta warga dunia yang cinta damai. Dalam rangka mewujudkan hal tersebut, lebih lanjut dalam Permendiknas Nomor 22 Tahun 2006, ditegaskan bahwa "Mata pelajaran IPS disusun secara sistematis, komprehensif, dan terpadu dalam proses pembelajaran menuju kedewasaan dan keberhasilan dalam kehidupan di masyarakat. Dengan pendekatan tersebut diharapkan peserta didik akan memperoleh pemahaman yang lebih luas dan mendalam pada bidang ilmu yang berkaitan". 
Oleh karena itu, tujuan mata pelajaran IPS sebagaimana disebutkan dalam Permendiknas Nomor 22 Tahun 2006 itu, bahwa mata pelajaran IPS bertujuan agar peserta didik memiliki kemampuan sebagai berikut: 1) mengenal konsep-konsep yang berkaitan dengan kehidupan masyarakat dan lingkungannya; 2) memiliki kemampuan dasar untuk berpikir logis dan kritis, rasa ingin tahu, inkuiri, memecahkan masalah, dan keterampilan dalam kehidupan sosial; 3) memiliki komitmen dan kesadaran terhadap nilai-nilai sosial dan kemanusiaan; 4) memiliki kemampuan berkomunikasi, bekerjasama dan berkompetisi dalam masyarakat yang majemuk, di tingkat lokal, nasional, dan global. Namun kondisi pendidikan IPS sekaligus sebagai permasalahan mendasar pendidikan IPS di sekolah diungkapkan oleh Solihatin (2012), yaitu (1) masih menggunakan model pembelajaran konvensional, (2) tujuan pendidikan IPS sulit dicapai, (3) siswa menjadi objek pembelajaran, (4) teacher centre, (5) kurang mendorong dan merangsang siswa untuk mengembangkan potensi inkuiri, (6) materi IPS masih bersifat hafalan, (7) evaluasi hanya sebatas pada kognitif, (8) prestasi siswa tidak dioptimalkan, dan (9) pola interaksi dalam pembelajaran masih bersifat satu arah. Kelemahan pendidikan IPS yang berkaitan dengan pembahasan ini adalah bersumber dari Susanto (2014), Pendidikan IPS dikatakan tidak bisa memberikan makna dari apa yang telah dipelajari, sehingga dianggap hanya untuk kepentingan sesaat tanpa ada manfaat praktis dalam kehidupan sehari-hari di masyarakat dan belum menjadikan nilai sosial budaya yang dikembangkan di lingkungan masyarakat menjadi sumber belajar siswa. Lebih jelas diungkapkan bahwa hambatan dalam mempraktikkan pembelajaran IPS bahwa buku pelajaran pada tingkat menengah tidak mengikuti alur pendekatan proses pengambilan keputusan dan pendekatan pemecahan masalah (Soemantri, 2001 : 133). Materi pelajaran IPS yang digunakan sebagai sumber belajar peserta didik terbatas pada buku-buku teks yang disediakan pemerintah.

Buku teks yang digunakan guru dalam pembelajaran IPS lebih banyak memaparkan materi yang masih bersifat umum. Kondisi ini berdampak pada buku teks yang disediakan oleh pemerintah tidak bersifat kontekstual serta tidak bersentuhan langsung pada aspek-aspek lokal. Aspek-aspek lokal yang dimaksud adalah keunggulan lokal yang dimiliki oleh masyarakat sebagai lingkungan peserta didik berada, yang harus dijadikan sebagai pondasi dalam mengembangkan materi IPS. Keunggulan lokal yang dimiliki seperti, potensi sumber daya alam, peninggalanpeninggalan sejarah, ungkapan-ungkapan lokal serta kondisi sosial budaya pada suatu daerah dapat dijadikan sumber belajar dalam pengembangan materi pembelajaran IPS. Materi IPS yang bersumber dari nilai-nilai kearifan lokal diharapkan dapat berfungsi untuk membangun jati diri dan karakter di tengah arus globalisasi. Hal ini dibuktikan dengan materi, metode dan evaluasi pembelajaran yang digunakan oleh guru IPS itu sendiri. Seperti yang diungkapkan oleh salah seorang pelajar di SMPN 4 Jerowaru bahwa selama pelajaran IPS mereka tidak pernah diajak mengamati kondisi masyarakat secara langsung dan pembelajaran hanya sebatas di ruang kelas saja. Hal ini dibuktikan dengan praktik pembelajaran IPS di SMPN 4 Jerowaru dibatasi pada penggunaan buku teks sebagai sumber materi pembelajaran. Berdasarkan pengamatan dan wawancara tentang bahan ajar khususnya buku teks kelas VIII yang digunakan guru dalam proses pembelajaran IPS adalah BSE karangan Sugiharsono dkk, tahun 2008 dan Sutanto dkk, tahun 2013 yang diterbitkan Pusat Perbukuan, Departemen Pendidikan Nasional. Oleh karena itu pembelajaran IPS di sekolah menjadi tidak kontesktual.

Oleh karena itu, untuk menuju ke arah itu, hendaknya guru IPS memahami, melaksanakan dan memegang teguh tentang landasan-landasan pendidikan IPS, yang terdiri dari: "landasan filosofis, ideologis, sosiologis, antropologis, kemanusian, politis, psikologis, dan landasan religius" (Sapriya, 2009). Sikap setiap guru IPS dalam memahami, melaksanakan dan memegang teguh tentang landasan-landasan pendidikan IPS, dalam rangka membentuk dan memiliki wawasan vertikal dan wawasan horizontal pada diri, tidak saja menyangkut pemahaman tentang ilmu-ilmu sosial dan nilai-nilai kemanusiaan secara umum, tetapi bertalian juga dengan pemahaman mengenai nilai-nilai kearifan lokal yang ada di masyarakat setempat, di mana mereka melaksanakan tugas. Sebab nilai-nilai sosio-kultural yang berkembang secara nasional akan lebih 
mudah dipahami dan dikembangkan, baik oleh guru itu sendiri maupun bagi peserta didik, apabila kita memiliki pengetahuan dan pemahaman terhadap nilai-nilai kearifan lokal masyarakat setempat, yang merupakan sumber dan dasar dari pengembangan nilai-nilai sosio-kultural masyarakat atau bangsa Indonesia yang majemuk.

Adanya nilai-nilai kearifan lokal tersebut mestinya mampu dijadikan sebagai suplemen pembelajaran IPS dan tentunya mampu diformulasikan ke dalam bentuk materi ajar yang kemudian dijadikan sebagai sarana pembentuk dan penanaman nilai-nilai yang terkandung dalam kearifan lokal tersebut. Seperti yang diungkapkan oleh pengamat pariwisata dari akademi pariwisata yaitu Drs. I Putu Gede M.Par mengatakan bahwa aspek kultur budaya dan kearifan lokal yang dimiliki Lombok menjadi hal yang perlu dipertahankan. Ia menilai, sulit kiranya Lombok bisa meraih berbagai penghargaan internasional jika tidak mempertahankan unsur kearifan lokal (suarantb.com, 2017). Dapat disimpulkan bahwa selain bermanfaat sebagai pembentuk karakter peserta didik, kearifan lokal juga memberikan penguatan jati diri atau identitas sebagai orang Sasak dan nantinya mampu mengembangkan eksistensi dirinya sendiri dan masyarakat umumnya (Adipta, 2018).

Tidak bisa dipungkiri bahwa realitas saat ini, nilai-nilai luhur yang pernah ada dan yang sudah diwariskan oleh para leluhur suku sasak saat ini sudah mengalami kehilangan arah dan makna. Sebagai contoh, dalam suku sasak dikenal adanya tradisi "ngongkolan". Tradisi "nyongkolan" ini dulunya dilakukan oleh warga sasak dengan begitu tertib, damai dan sesuai dengan etika yang ada. Akan tetapi akhir-akhir ini tradisi "nyongkolan" tersebut dijadikan sebagai sarana untuk melampiaskan mabok-mabokan dari para pemuda dan juga melakukan joget-joget yang kurang etis untuk dipandang (Adipta, 2018). Lemahnya nilai-nilai yang ada di dalam masyarakat tersebut terjadi karena lemahnya pengamalan pedoman maupun pegangan atau acuan hidup dari masyarakat untuk memfilter terjadinya pengaruh kemajuan zaman, ilmu pengetahuan dan teknologi atau globalisasi, serta laju pembangunan yang tidak didasarkan atas budaya masyarakat setempat. Lemahnya proses regenerasi terhadap kearifan lokal yang ada di suku sasak tentu mengurangi pemahaman dari para generasi penerus untuk selalu mempedomani nilai-nilai yang ada di dalam masyarakat sasak itu sendiri.

Hal ini menjadi semakin urgen, mengingat hasil pengamatan selama ini di lapangan tepatnya di beberapa wilayah di Kecamatan Jerowaru bahwa semakin lemahnya nilai-nilai sikap, tingkah laku bahkan tidak lepas dari sifat individualistis, seperti sikap yang mau menang sendiri, suka memaksakan kehendak, kurang mengakui pihak lain, sikap toleransi yang semakin melemah, kurangnya rasa simpati bahkan empati terhadap orang lain dan sebagainya. Selain itu, kurangnya penghormatan terhadap orang yang lebih tua, apatis terhadap suatu permasalahan, cenderung kurang bertanggungjawab atas kesalahan yang mereka perbuat, hilangnya kebiasaan silaturahmi, kurangnya sikap saling mengingatkan satu sama lain, lebih cenderung menyelesaikan konflik dengan kekerasan (tawuran), dan kurangnya keikutsertaan dalam kehidupan sosial. Senada dengan itu, menurut L. Jupri Ihsan, S.Sos, selaku kepala desa Jerowaru dan tokoh masyarakat mengemukakan bahwa sikap dan perilaku masyarakat desa Jerowaru saat ini jauh dari nilai-nilai yang terkandung dalam kearifan lokal yang ada. Hal ini dibuktikan dengan banyaknya pemuda yang suka mabok-mabokkan dan kurang memiliki sopan santun terhadap orang yang lebih tua serta sikap toleransi yang ada di masyarakat sudah mulai memudar.

Hal ini juga dibuktikan dengan pendapat Nursam, S.Pd, selaku Kepala Sekolah SMPN 4 Jerowaru menjelaskan mengenai perubahan perilaku dari siswa kini sudah mulai adanya perubahan. Perubahan yang mencolok di kalangan siswa khususnya siswa-siswa di SMP Negeri 4 Jerowaru yaitu dari pola laku, tutur kata, cara berpakaian, fasion, dan lain sebagainya. Perilakuperilaku tersebut bukan hal yang tidak wajar akan tetapi cukup berbeda dari ghiroh nilai-nilai kearifan lokal yang kita miliki. Bahkan pemerintah sudah sering melakukan sosialisasi terhadap para guru untuk terus menanamkan nilai-nilai karakter bangsa kepada siswa tetapi itu juga tergantung dari pengaruh lingkungan dari pada siswa itu sendiri. Kami sudah berupaya 
melakukan hal-hal sebaik mungkin, baik itu dalam bentuk program sekolah maupun instruksi kepada para guru untuk melakukan penanaman karakter kepada para siswa. Masih banyak para siswa yang kurang peduli terhadap temannya, lingkungannya bahkan dengan tanggung jawabnya sebagai seorang pelajar. Oleh karena itu sangat penting untuk menanamkan nilai-nilai kearifan lokal suku Sasak dalam pembelajaran IPS di sekolah.

Beranjak dari pendapat itu, berarti unsur-unsur lokal dalam pembelajaran IPS yang selama ini berlangsung di sekolah telah dikesampingkan, dan proses pembelajarannya masih menggunakan cara konvensional atau tradisional. Oleh karena itu, pembelajaran IPS selama ini khususnya yang ada di Kecamaan Jerowaru belum mampu mengarahkan atau mewujudkan peserta didik untuk menjadi warga negara Indonesia yang demokratis, dan bertanggung jawab, serta warga dunia yang cinta damai sesuai dengan tujuan IPS itu sendiri. Atas dasar itu, berarti pembelajaran IPS belum sepenuhnya mampu mencapai dan merealisasikan tujuan yang telah ditetapkan, yang terdiri dari 4 (empat) tujuan seperti telah disebutkan dalam Permendiknas Nomor 22 Tahun 2006.

Keadaan yang mengkhawatirkan itu menuntut adanya upaya untuk menerapkan nilai-nilai luhur tersebut dalam kehidupan masyarakat Sasak dewasa ini, sehingga generasi muda tidak tercabut dari akar budayanya sendiri. Usaha ini akan efektif dilakukan melalui pendidikan, dan membangun kembali kesepakatan antar kelompok yang ada dalam komunitas Sasak itu sendiri secara sungguh-sungguh untuk memformat kembali nilai-nilai luhur tersebut, menyesuaikannya dengan kehidupan masa kini dan diformulasikan dengan baik sebagai modal untuk menghadapi tantangan masa depan. Penanaman nilai-nilai kearifan lokal tersebut tentu ditujukan untuk mengaplikasikan nilai-nilai luhur tersebut dalam kehidupan bermasyarakat secara holistik. Sejalan dengan itu menurut Asmani (2012) dalam Abdullah (2020) menyebutkan peran nilai kearifan lokal dalam proses pendidikan adalah agar peserta didik dapat mengetahui, memahami, menganalisis dan kemudian mengembangkan keunggulan lokal daerah tempat mereka tinggal. Serta dapat memahami seluruh aspek dan fungsi dari nilai-nilai yang terkandung dalam kearifan lokal dalam membangun karakter dari peserta didik tersebut.

Dalam usaha pengembangan nilai-nilai sosial dan budaya masyarakat Sasak yang kini sudah mulai memudar, maka perlu adanya kesadaran diri maupun tindakan khusus bagi para guru untuk melakukan perbaikan dalam setiap perubahan kehidupan, khususnya bagi siswa untuk dapat menjalankan kehidupannya kelak sesuai dengan yang diharapkan. Pengembangan tersebut dilakukan dengan menyesuaikan dan menyisipkan nilai-nilai sosial dan budaya lokal masyarakat Sasak yang ada terhadap materi yang sesuai dengan Kompetensi Dasar. Transformasi nilai-nilai kearifan lokal masyarakat Sasak melalui pendidikan, terutama melalui pembelajaran IPS menjadi sangat urgen dan relevan, karena akan mampu mengarahkan peserta didik untuk dapat menjadi warga negara Indonesia yang demokratis, bertanggung jawab, dan cinta damai. Maksudnya adalah pengembangan sikap dan prilaku berdemokrasi, bertanggung jawab, dan cinta damai, dapat dilakukan dengan menerapkan suplemen materi pembelajaran IPS melalui kajian kearifan lokal masyarakat setempat.

Untuk mencapai ke arah itu, maka pembelajaran IPS tidak semata-mata dipandang sebagai upaya mentransfer pengetahuan, tetapi lebih dari itu harus dapat dijadikan sebagai kekuatan pada setiap kehidupan peserta didik, karena pengajaran IPS sangat terkait dengan nilai-nilai demokrasi dan partisipasi positif warga negara. Secara singkat dapat dikatakan bahwa Pembelajaran IPS bertujuan untuk mengembangkan pada diri siswa pengetahuan yang dapat dimanfaatkan bagi kepentingan diri dan masyarakatnya (Rachmah, 2014). Akan tetapi jika kita perhatikan bersama bahwa selama ini harapan-harapan tersebut jauh dari kenyataan. Seperti yang diungkapkan oleh (Lasmawan, 2010) bahwa selama ini, pendidikan di sekolah-sekolah hanya sebatas mentransfer ilmu pengetahuan, tidak membangun karakter anak didik, dan siswa tidak diberi kesempatan untuk merefleksikan dan memposisikan dirinya dalam sistem pendidikan yang semata-mata untuk kepentingan dunia kerja. Kegiatan refleksi di dalam 
pendidikan itu sangat penting, akan tetapi kegiatan refleksi kini sudah kehilangan tempat karena pendidikan selama ini masih memperlihatkan pola pendidikan yang mentransfer ilmu.

Jika mengacu pada apa yang menjadi tujuan pembelajaran IPS, pengembangan suplemen lain yang dapat dikemban gkan dalam materi IPS itu adalah lingkungan sekitar peserta didik, maka tidak heran jika kemudian masyarakat itu dianggap sebagai laboratorium pendidikan IPS. Perubahan dan permasalahan sosial dengan segala implikasinya yang semakin pesat dapat dikembangkan menjadi materi Pendidikan IPS (Rachmah, 2014). Lebih lanjut (Rachmah, 2014) mengatakan materi pelajaran IPS bahan-bahannya diambil dari kehidupan nyata di lingkungan masyarakat. Bahan atau materi yang diambil dari pengalaman pribadi, teman-teman sebaya, serta lingkungan alam, dan masyarakat sekitarnya. Hal ini dapat lebih mudah dipahami karena mempunyai makna lebih besar bagi para peserta didik dari pada bahan pengajaran yang abstrak dan rumit dari ilmu-ilmu sosial.

Permasalahan yang dipaparkan di atas merupakan permasalahan yang termasuk ke dalam dimensi teknis pendidikan. Jika kira renungi bersama bahwa pada hakikatnya kita terlalu terlena dengan permasalahan-permasalahan dalam dimensi teknis pendidikan, sehingga mengabaikan realitas problematika pendidikan yang sumbernya ada pada kawasan strategis lainnya, yaitu dimensi ideologis kultural (Widja, 2009). Lebih lanjut (Widja, 2009) menjelaskan bahwa permasalahan tersebut terutama menyangkut aspek-aspek praktik relasi kekuasaan, bisa persepsi kultural laten, ekspansi dominasi ideologi global (globalisasi), ilusi sebagai dampak budaya pencitraan (imagologi) dalam pendidikan, dan bahkan ilusi pencapaian kualifikasi pendidikan yang bersifat absurd. Untuk merealisasi hal itu maka Pendidikan IPS sejatinya harus mampu mengakomodasi proses budaya itu sendiri baik dalam proses transmisif (pewarisan budaya atau nilai), transisional (menyiapkan anak dalam transisi peran sosial kultural) dan transformatif (upaya mengantarkan anak agar tidak mengalami goncangan-goncangan atau konflik kejiwaan dalam transisi kehidupan sosial budayanya).

Oleh karena itu, untuk pengembangan dan menanam kembali nilai-nilai kearifan lokal suku Sasak dapat dilakukan melalui proses pembelajaran. Nilai-nilai luhur masyarakat suku Sasak itu, nantinya akan dijadikan sebagai suplemen pembelajaran yang nantinya dapat dimanfaatkan oleh guru IPS, khususnya di SMPN 4 Jerowaru. Suplemen pembelajaran tersebut tentunya disesuaikan dengan kompetensi dasar yang telah ditentukan dan dirumuskan dalam silabus. Bertalian dengan semua itu, penelitian ini bertujuan untuk (1) Mengetahui nilai-nilai sosial dan budaya masyarakat suku Sasak yang dapat dimanfaatkan sebagai suplemen materi ajar IPS di SMP Negeri 4 Jerowaru, (2) Untuk mengetahui keterkaitan nilai kearifan lokal masyarakat suku Sasak yang dapat dijadikan sebagai suplemen materi ajar IPS di SMPN 4 Jerowaru, (3) Menghasilkan nilai-nilai sosial dan budaya yang terdapat dalam kearifan lokal masyarakat suku Sasak dikembangkan sebagai suplemen bahan ajar dalam pembelajaran IPS di SMPN 4 Jerowaru.

\section{Metode}

Penelitian ini menggunakan penelitian pengembangan yang dilakukan dengan mengadopsi model 4-D yaitu define, design, develop dan dessaminate (Thiagarajan. Semmel, dan Seinmel, 1974 dalam Trianto, 2010) yang dimodifikasi menjadi model 3-D, yaitu tahap define (pendefinisian) dilakukan tahap mengidentifikasi potensi dan masalah, tahap pengumpulan data, tahap analisis komptensi dasar pada kurikulum 2013, tahap design (perancangan) dilakukan tahap mendesain suplemen materi ajar IPS, dan tahap develop (pengembangan) dilakukan tahap validasi suplemen materi ajar IPS dari ahli IPS, tahap uji coba kelayakan bahan ajar, tahap uji kepraktisan bahan ajar dan produk final dari bahan ajar. Langkah ke empat, yaitu dessaminate tidak dilakukan dalam penelitian ini, karena merupakan penelitian dalam rangka penyelesaian studi yang memiliki batas waktu dan biaya. Subjek daam penelitian ini adalah informan inti yang meliputi: tokoh adat, tokoh masyarakat, masyarakat dan siswa. Instrumen dalam penelitian ini 
adalah menggunakan pedoman wawancara, lembar penilaian bahan ajar dan validasinya oleh para ahli di bidang IPS dan Guru mata pelajaran IPS. Teknik analisis data adalah dengan menggunakan teknik Gregory dan Tingkat pencapaian dengan skala 5 untuk tahap define, design, dan develop.

\section{Hasil dan Pembahasan}

\section{Nilai-Nilai Sosial dan Budaya Masyarakat Suku Sasak Yang Dapat Dimanfaatkan Sebagai Suplemen Materi Ajar IPS di SMP Negeri 4 Jerowaru}

Adapun wujud nilai sosial dan budaya masyarakat suku Sasak yang dapat dimanfaatkan sebagai suplemen materi ajar IPS di SMP Negeri 4 Jerowaru sebagai berikut.

\section{Nilai Sosial Masyarakat Suku Sasak}

Kearifan lokal masyarakat suku Sasak di Kecamatan Jerowaru mengandung nilai sosial yang dapat memperkuat hubungan antara sesama manusia di dalam masyarakat. Adapun wujud nilai sosial yang terkandung di dalam kearifan lokal masyarakat suku Sasak di Kecamatan Jerowaru yaitu kearifan lokal besiru. Kearifan lokal ini merupakan salah satu bentuk perilaku sosial masyarakat suku Sasak yang terkait dengan masalah solidaritas dan integritas antara sesama. Kearifan lokal besiru adalah kegiatan gotong royong bekerja di sawah, mulai dari mengelola tanah pertanian, menanam hingga pelaksanaan panen secara bergilir tanpa upah. Sementara begawe dan besentulak mengandung nilai-nilai sosial seperti menghidupkan kembali keramah-tamahan, membangkitkan jiwa gotong royong, meningkatkan jalinan silaturahmi, menciptakan kebersamaan, menumbuhsuburkan rasa berbagi, mempererat tali ukhuwah. Adapaun aktualisasi nilai-nilai sosial dalam besiru, begawe dan besentulak sangat penting dilakukan di era kekinian melalui pembelajaran IPS, terutama yang berkenaan dengan materi interaksi sosial, berbasis pada fenomena sosial budaya dan pranata sosial yang terdapat dimasyarakat.

\section{Nilai Budaya Masyarakat Suku Sasak}

Kearifan lokal masyarakat suku Sasak di Kecamatan Jerowaru yang mengandung nilai budaya yang dapat memperkuat hubungan antara sesama manusia di dalam masyarakat. Adapun wujud nilai budaya yang terkandung di dalam kearifan lokal masyarakat suku Sasak di Kecamatan Jerowaru yaitu kearifan lokal begawe, besentulak, gendeng beleq dan peresean. Dimana dari keempat kearifan loal tersebut mengandung nilai melestarikan budaya. Namun untuk kearifan lokal gendeng beleq ini biasanya digunakan pada saat anggota masyarakat yang sedang nyongkolan (arak-arakan pengantin dan mengantarkan mempelai wanita kepada keluarganya sampai kembali lagi ke rumah mempelai pria) dan kearifan lokal peresean merupakan sebuah tarian yang dilakukan antara dua laki-laki untuk bertarung antara satu dengan yang lainnya untuk menunjukkan keperkasaannya. Adapaun aktualisasi nilai melestarikan budaya dan tradisi dalam begawe, besentulak, gendang beleq dan peresean sangat penting dilakukan di era kekinian melalui pembelajaran IPS, terutama yang berkenaan dengan berbasis pada fenomena sosial budaya dan pranata sosial yang terdapat dimasyarakat. Adapaun gambar dari masing-masing kearifan lokal suku Sasak sebgai berikut. 


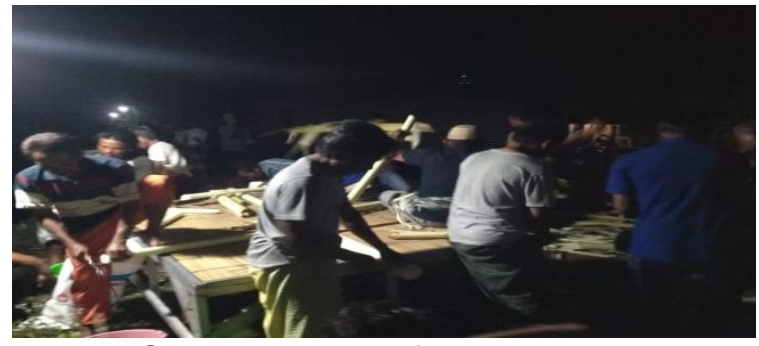

Gambar 01. Kearifan Lokal Begawe Sumber :Yunan, 2021

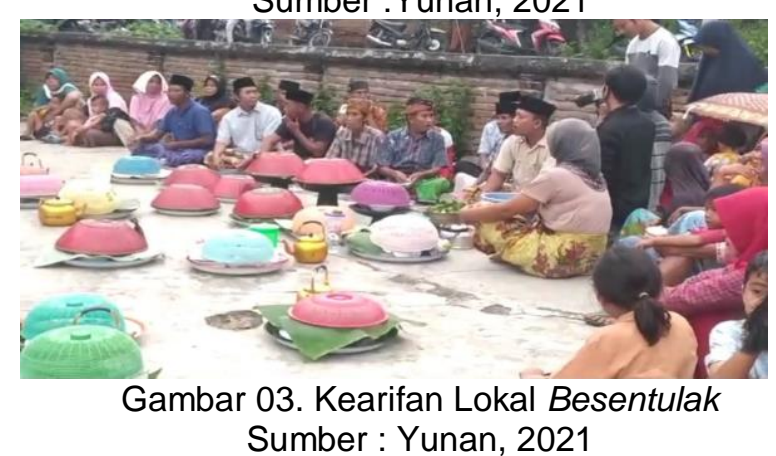

Sumber : Yunan, 2021

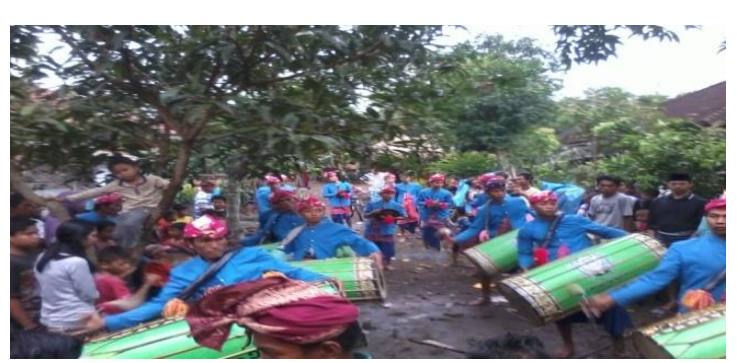

Gambar 02. Kearifan Lokal Gendang Beleq Sumber : Yunan, 2020

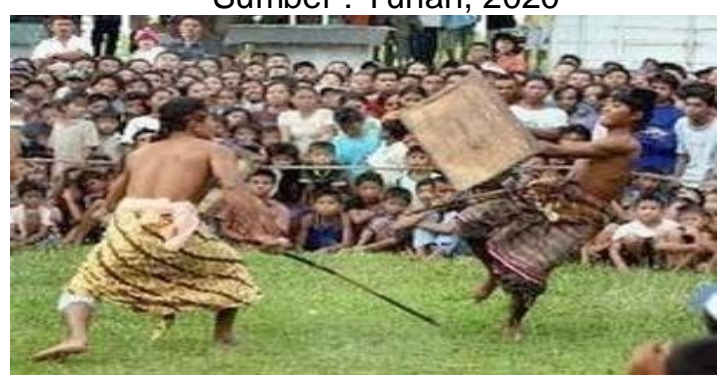

Gambar 04. Kearifan Lokal Peresean Sumber : http://peresean.blogspot.co.id/

\section{Keterkaitan Nilai Kearifan Lokal Masyarakat Suku Sasak Dengan Tujuan dan Ruang Lingkup Materi IPS SMPN 4 Jerowaru}

Keterkaitan nilai kearifan lokal masyarakat suku Sasak dijadikan sebagai suplemen materi ajar IPS di SMPN 4 Jerowaru adalah sangat penting dan terkait. Hal ini disebabkan, karena nilai kearifan lokal dapat mendukung tujuan dan ruang lingkup materi IPS SMP, seperti kearifan lokal besiru mampu mendukung kesadaran peserta didik terhadap nilai-nilai sosial dan kemanusiaan dan berkaitan dengan materi bentuk-bentuk interaksi sosial; kearifan lokal begawe mampu mendukung peserta didik memiliki kemampuan berkomunikasi, bekerjasama dan berkompetisi dalam masyarakat yang majemuk, di tingkat lokal, nasional, dan global dan berkaitan dengan materi bentuk-bentuk interaksi sosial dan pranata sosial; dan kearifan lokal besentulak mampu mendukung peserta didik untuk mengenal konsep-konsep yang berkaitan dengan kehidupan masyarakat dan lingkungannya dan berkaitan dengan materi bentuk-bentuk interaksi sosial dan pranata sosial serta pengaruhnya terhadap masyarakat sekitar. Hasil penelitian ini juga didukung oleh penelitian Suparmini, dkk (2013) mengemukakan bahawa kearifan lokal dipandang sangat bernilai dan mempunyai manfaat tersendiri dalam kehidupan masyarakat. Hal ini juga didukung oleh penelitian Sriyanti dan Sriartha (2019) yang menunjukan kearifan lokal Subak sebagai sumber belajar mengandung nilai-nilai karakter bangsa yaitu gotong royong, peduli lingkungan dan peduli sosial. Hal ini juga didukung oleh penelitian Adipta (2018) mengemukakan arti penting nilai-nilai kearifan lokal suku Sasak dijadikan sebagai suplemen materi ajar IPS karena kearifan lokal suku Sasak dapat dijadikan sebagai pedoman dalam kehidupan bermasyarakat. Selain itu Idris (2012) dalam Herliani, dkk (2020) menyebutkan kearifan lokal meliputi seluruh aspek kehidupan, seperti aturan yang menyangkut hubungan antara sesama manusia, hubungan manusia dengan alam, dan hubungan manusia dengan Tuhan. Peranan penting dari kearifan lokal masyarakat suku Sasak harus dipahami oleh setiap elemen masyarakat sebagai bentuk warisan kekayaan dari para leluhur. Adapun fungsi kearifan lokal masyarakat suku Sasak adalah sebagai berikut. 1) Sebagai pedoman dalam berprilaku dalam masyarakat. 2) Sebagai pedoman untuk menjaga hubungan antara manusia dengan lingkungan. 3) Sebagai pedoman untuk menjaga hubungan antara manusia dengan tuhan. 4) Kearifan lokal sebagai identitas suku Sasak. 


\section{Nilai-Nilai Sosial dan Budaya Yang Terdapat Dalam Kearifan Lokal Masyarakat Suku Sasak Dikembangkan Sebagai Suplemen Bahan Ajar Dalam Pembelajaran IPS di SMPN 4 Jerowaru}

Pengembangan suplemen ditentukan dengan tujuan pembelajaran yang ingin dicapai. Suplemen pembelajaran tidak dapat menggantikan peran perangkat pembelajaran utama, karena hanya berfungsi sebagai pelengkap. Suplemen pembelajaran dipergunakan untuk mencapai tujuan yang tidak dapat dicapai oleh perangkat pembelajaran yang telah tersedia. Suplemen materi ajar IPS ini dilakukan dengan tiga cara, yaitu tahap pendefinisian (define) yang terdiri dari tahapan mengidentifikasi potensi masalah, kemudian dilakukan dengan menganalisis kompetensi dasar yang sesuai dengan tema dalam penelitian ini, khususnya yang terkait dengan nilai-nilai kearifan lokal. Kearifan lokal beserta nilai-nilai yang terkandung di dalamnya didapatkan dari proses penelitian dengan menggunakan berbagai teknik pengumpulan data yang kemudian dilakukan berbagai proses analisis sehingga menghasilkan kesimpulan yang utuh dari berbagai data yang didapatkan.

Data yang sudah final inilah nantinya akan dijadikan sebagai suplemen materi ajar mata pelajaran IPS di SMP. Setelah kompetensi dasar ditentukan maka dilakukan adaptasi terhadap materi yang dijadikan sebagai panduan untuk menyisipkan suplemen materi yang sudah ada. Dalam hal ini materi panduan yang digunakan peneliti adalah buku mata pelajaran IPS kelas VIII kurikulum tingkat satuan pendidikan yang dterbitkan oleh Departemen Pendidkan Nasional, Jurnal yang ditulis oleh Sriyanti, Ni Nyoman Mira dan I Putu Sriartha. 2019 berjudul "Pengembangan Sumber Belajar IPS Berbasis Kearifan Lokal Sistem Subak Dalam Membangun Nilai Karakter Siswa". Jurnal PIPS, Vol. 3 No. 2, Bulan Oktober Tahun 2019, ISSN:2614-8366 dan Jurnal yang ditulis oleh Herliani, dkk. 2020 berjudul "Pengembangan Suplemen Materi IPS Dengan Pemanfaatan Potensi Budaya Masyarakat Berlandaskan Tri Hita Karana". Jurnal Pendidikan IPS Indonesia, Vol. 4 No. 2, Bulan Oktober Tahun 2020 p-ISSN:2614-8366, e-ISSN:2686-1925. Setiap sub materi yang ada pada kompetensi dasar akan disisipkan dengan konsep-konsep yang berkaitan dengan nila-nilai kearifan lokal suku Sasak. Selain dari pada itu, akan disajikan dengan mencantumkan beberapa gambar yang relevan terkait materi yang akan dijadikan suplemen materi ajar dan dilengkapi dengan beberapa pertanyaan sebagai bentuk review pemahaman siswa terhadap materi yang akan diajarkan. Kemudian akan disesuaikan atau diadaptasi pula ke dalam Rencana Pelaksanaan Pembelajaran (RPP). Suplemen materi ajar yang telah disusun agar lebih layak untuk dijadikan sebagai bahan ajar maka akan dilakukan tahap pengembangan (develop) yaitu dilakukan tahapan divalidasi oleh validator yang ahli dalam bidang ke IPSan dan tahapan uji coba kelayakan bahan ajar oleh ahli dan praktisi dengan hasil 86,82 \% katagori baik sedikit revisi, serta dilakukan tahapan uji kepraktisan bahan ajar oleh siswa di kelas VIII 1 dengan hasil 88,32 \% katagori baik sedikit revisi, sampai pada bentuk akhir produk bahan ajar IPS tersebut jadi. Sehingga layak dan praktis digunakan sebagai bahan ajar IPS di SMP Negeri 4 Jerowaru.

Suplemen materi ajar akan mempermudah para siswa untuk memahami materi yang sesuai dengan kebutuhannya, seperti pengenalan terhadap sosial dan budaya yang ada di lingkungan masyarakatnya sendiri. Selain itu, dari suplemen materi ajar dapat menambah khasanah ilmu pengetahuan dan juga memperkaya kegiatan pembelajaran. Seperti yang diungkapkan oleh Nurhajati (2015) dalam penelitiannya bahwa suplemen bahan ajar disusun guna memperkaya kegiatan pembelajaran dan memberikan variasi aktivitas pembelajaran di kelas. Suplemen bahan ajar ini disusun berdasarkan kebutuhan guru maupun siswa yang akan mempergunakannya sesuai masukan yang telah diberikan seperti, materi harus relevan dengan KD.

Pengembangan materi ajar ataupun penyusunan suplemen materi ajar berbasis kearifan lokal dapat membentuk kognitif dan mengembangkan karakter dari para siswa. Hal ini terbukti dari hasil penelitian yang dilakukan oleh Mannan, dkk (2015) bahwa pengembangan perangkat pembelajaran berbasis kearifan lokal telah mampu mengembangkan karakter positif siswa. Selain itu, pengintegrasian perangkat pembelajaran dengan kearifan lokal efektif dalam meningkatkan 
aspek kognitif siswa. Hal ini juga didukung oleh penelitian Ramastuti, dkk (2018) menunjukan pengembangan bahan ajar IPS bermuatan kearifan lokal Bali dapat membentuk siswa yang mampu bertahan dan beradaptasi dengan arif dan bijaksana di tengah arus globalisasi dengan memegang teguh nilai-nilai peduli sosial dan etika lingkungan. Hal ini juga didukung oleh penelitian Herliani, dkk (2020) yang menunjukan secara umum pengembangan handout materi telah mampu meningkatkan hasil belajar baik kognitif, afektif dan psikomotor. Handout materi yang dikembangkan mampu memberikan kondisi riil di lapangan yang dapat meningkatkan pengetahuan dan pemahaman siswa bahwa apa yang mereka pelajari tidak hanya sebatas anganangan, khususnya terkait materi bentuk-bentuk interaksi sosial. Pemberian suplemen dalam bentuk handout materi juga telah mampu meningkatkan hasil belajar sikap, meskipun tidak secara keseluruhan dari aspek sikap yang ditentukan. Keterampilan siswa dalam menentukan kegiatan-kegiatan masyarakat yang mencerminkan adanya interaksi sosial juga semakin meningkat.

\section{Simpulan dan Saran}

Adapun wujud nilai sosial dan budaya masyarakat suku sasak yang dapat dimanfaatkan sebagai suplemen materi ajar IPS di SMPN 4 Jerowaru sebagai berikut, yaitu: Kearifan lokal besiru, begawe, besentulak, gendeng beleq dan peresean. Kearifan lokal ini mengandung nilai-nilai sosial dan budaya seperti menghidupkan kembali keramah-tamahan, membangkitkan jiwa gotong royong, meningkatkan jalinan silaturahmi, menciptakan kebersamaan, menumbuhsuburkan rasa berbagi, mempererat tali ukhuwah dan nilai melestarikan budaya.

Keterkaitan nilai kearifan lokal masyarakat suku Sasak dijadikan sebagai suplemen materi ajar IPS di SMPN 4 Jerowaru adalah sangat penting dan terkait. Hal ini disebabkan, karena nilai kearifan lokal dapat mendukung tujuan dan ruang lingkup materi IPS SMP, seperti kearifan lokal besiru mampu mendukung kesadaran peserta didik terhadap nilai-nilai sosial dan kemanusiaan dan berkaitan dengan materi bentuk-bentuk interaksi sosial; kearifan lokal begawe mampu mendukung peserta didik memiliki kemampuan berkomunikasi, bekerjasama dan berkompetisi dalam masyarakat yang majemuk, di tingkat lokal, nasional, dan global dan berkaitan dengan materi bentuk-bentuk interaksi sosial dan pranata sosial; dan kearifan lokal besentulak mampu mendukung peserta didik untuk mengenal konsep-konsep yang berkaitan dengan kehidupan masyarakat dan lingkungannya dan berkaitan dengan materi bentuk-bentuk interaksi sosial dan pranata sosial serta pengaruhnya terhadap masyarakat sekitar.

Pengembangan suplemen ditentukan dengan tujuan pembelajaran yang ingin dicapai. Suplemen pembelajaran tidak dapat menggantikan peran perangkat pembelajaran utama, karena hanya berfungsi sebagai pelengkap. Suplemen pembelajaran dipergunakan untuk mencapai tujuan yang tidak dapat dicapai oleh perangkat pembelajaran yang telah tersedia. Suplemen materi ajar IPS ini dilakukan dengan tiga cara, yaitu tahap pendefinisian (define) yang terdiri dari tahapan mengidentifikasi potensi masalah, kemudian dilakukan dengan menganalisis kompetensi dasar yang sesuai dengan tema dalam penelitian ini, khususnya yang terkait dengan nilai-nilai kearifan lokal suku Sasak. Kearifan lokal beserta nilai-nilai yang terkandung di dalamnya didapatkan dari proses penelitian dengan menggunakan berbagai teknik pengumpulan data yang kemudian dilakukan berbagai proses analisis sehingga menghasilkan kesimpulan yang utuh dari berbagai data yang didapatkan.

Data yang sudah final inilah nantinya akan dijadikan sebagai suplemen materi ajar mata pelajaran IPS di SMP. Setelah kompetensi dasar ditentukan maka dilakukan adaptasi terhadap materi yang dijadikan sebagai panduan untuk menyisipkan suplemen materi yang sudah ada. Dalam hal ini materi panduan yang digunakan peneliti adalah buku mata pelajaran IPS kelas VIII kurikulum tingkat satuan pendidikan yang diterbitkan oleh Departemen Pendidkan Nasional, Jurnal yang ditulis oleh Sriyanti, Ni Nyoman Mira dan I Putu Sriartha. 2019 berjudul 
"Pengembangan Sumber Belajar IPS Berbasis Kearifan Lokal Sistem Subak Dalam Membangun Nilai Karakter Siswa". Jurnal PIPS, Vol. 3 No. 2, Bulan Oktober Tahun 2019, ISSN:2614-8366 dan Jurnal yang ditulis oleh Herliani, dkk. 2020 berjudul "Pengembangan Suplemen Materi IPS Dengan Pemanfaatan Potensi Budaya Masyarakat Berlandaskan Tri Hita Karana". Jurnal Pendidikan IPS Indonesia, Vol. 4 No. 2, Bulan Oktober Tahun 2020 p-ISSN:2614-8366, e-ISSN:2686-1925. Setiap sub materi yang ada pada kompetensi dasar akan disisipkan dengan konsep-konsep yang berkaitan dengan nila-nilai kearifan lokal suku Sasak. Selain dari pada itu, akan disajikan dengan mencantumkan beberapa gambar yang relevan terkait materi yang akan dijadikan suplemen materi ajar dan dilengkapi dengan beberapa pertanyaan sebagai bentuk review pemahaman siswa terhadap materi yang akan diajarkan. Kemudian akan disesuaikan atau diadaptasi pula ke dalam Rencana Pelaksanaan Pembelajaran (RPP). Suplemen materi ajar yang telah disusun agar lebih layak untuk dijadikan sebagai bahan ajar maka akan dilakukan tahap pengembangan (develop) yaitu dilakukan tahapan divalidasi oleh validator yang ahli dalam bidang ke IPSan dan tahapan uji coba kelayakan bahan ajar oleh ahli dan praktisi dengan hasil 86,82 \% katagori baik sedikit revisi, serta dilakukan tahapan uji kepraktisan bahan ajar oleh siswa di kelas VIII 1 dengan hasil 88,32 \% katagori baik sedikit revisi, sampai pada bentuk akhir produk bahan ajar IPS tersebut jadi. Sehingga layak dan praktis digunakan sebagai bahan ajar IPS di SMP Negeri 4 Jerowaru. Suplemen materi ajar akan mempermudah para siswa untuk memahami materi yang sesuai dengan kebutuhannya, seperti pengenalan terhadap sosial dan budaya yang ada di lingkungan masyarakatnya sendiri. Selain itu, dari suplemen materi ajar dapat menambah khasanah ilmu pengetahuan dan juga memperkaya kegiatan pembelajaran.

Adapun saran yang dapat diberikan terkait dengan hasil penelitian ini adalah sebagai berikut. Bagi guru IPS hendaknya selalu melakukan pengembangan suplemen materi ajar yang disesuaikan dengan kondisi dan potensi yang dimiliki oleh daerah itu sendiri, seperti kearifan lokal daerah tersebut. Bagi masyarakat dan pemerintah setempat hendaknya selalu mendukung dan selalu bersedia menjadi fasilitator membantu guru di sekolah, sehingga setiap stackholder bersama-sama dalam memberikan dan menanamkan nilai-nilai kearifan lokal bagi para generasi bangsa (siswa). Bagi peneliti lain diharapkan agar melakukan penelitian yang sejenis dengan bentuk dan variasi yang berbeda untuk memperkaya khasanah ilmu pengetahuan khususnya Ilmu Pengetahuan Sosial.

\section{Daftar Pustaka}

Abdullah, M. (2020). Manajemen Pendidikan Kontemporer (Kontruksi Pendekatan Berbasis Budaya dan Kearifan Lokal). Bandung: Penerbit Cendekia Press.

Adipta, M. (2018). Rekonstruksi Nilai-Nilai Kearifan Lokal Suku Sasak Sebagai Suplemen Materi Ajar Pendidikan IPS Pada SMP Negeri 3 Pujut Kabupaten Lombok Tengah. Jurnal Pendidikan, Sosial dan Budaya, 1(2).

Herliani, Isty Bunga. (2020). Pengembangan Suplemen Materi IPS Dengan Pemanfaatan Potensi Budaya Masyarakat Berlandaskan Tri Hita Karana. Jurnal Pendidikan IPS Indonesia, 4(2).

Lasmawan, W. (2010). Menelisik Pendidikan IPS dalam Perspektif Kontekstual-Empiris. Singaraja: Mediakom Indonesia Press Bali.

Mannan, M. N. (2015). Pengembangan Perangkat Pembelajaran Berbasis Kearifan Lokal untuk Mengembangkan Karakter Positif Siswa SD. Jurnal Inovasi dan Pembelajaran Fisika, 2(2).

Nurhajati, D. (2015). Pengembangan Suplemen Bahan Ajar Bahasa Inggris untuk Siswa SMP. Nusantara of Research Universitas Nusantara PGRI Kediri, 2(2).

Rachmah, I. (2014). Metode Penelitian Studi Media dan Kajian Budaya. Bandung: Penerbit Kencana. Ramastuti, N. W. (2018). Pengembangan Bahan Ajar IPS Berbentuk Handout Bermuatan Kearifan Lokal Bali Untuk Meningkatkan Nilai Peduli Sosial Dan Etika Lingkungan. Jurnal PIPS, (2)1.

Sapriya. (2009). Pendidikan IPS Konsep dan Pembelajaran. Bandung: PT Rosdakarya. 
Suarantb. (2017). Kalahkan Jepang, Lombok Harus Pertahankan Kearifan Lokal. Terdapat pada: https://www.suarantb.com/kalahkan.jepang.lombok.harus.pertahankan.keakeari.lokal/. Diakses pada: 6 Januari 2021.

Sriyanti, N. N. M., \& Sriartha, I. P. (2019). Pengembangan Sumber Belajar IPS Berbasis Kearifan Lokal Sistem Subak Dalam Membangun Nilai Karakter Siswa. Jurnal PIPS, 3(2)

Solihatin, E., \& Raharjo. (2012). Cooperative Learning: Analisis Model Pembelajaran IPS. Edisi 1, Cetakan Ke-6. Jakarta: Bumi Aksara.

Somantri, M. N. (2001). Menggagas Pembaharuan Pendidikan IPS. Bandung: Rosdakarya.

Susanto, A. (2014). Pengembangan Pembelajaran IPS di Sekolah Dasar, Edisi Pertama. Jakarta: Kencana Prenamedia Group.

Suparmini. (2013). Pelestarian Lingkungan Masyarakat Baduy Berbasis Kearifan Lokal. Jurnal Penelitian Humaniora, 18(1), 8-22.

Trianto. (2010). Mendesain Model Pembelajaran Inovatif-Progresif. Jakarta: Prenada Media.

Peraturan Menteri Pendidikan Nasional Nomor 22 Tahun 2006 Tentang Standar Isi dan Tujuan Pendidikan IPS.

Peraturan Menteri Pendidikan Nasional Nomor 23 Tahun 2006 Tentang Standar Kompetensi Lulusan (SKL) untuk mata pelajaran IPS tingkat SMP.

Undang-Undang Nomor 20 Tahun 2003 tentang Sistem Pendidikan Nasional.

Widja, I G. (2009). Pendidikan Sejarah dan Tantangan Masa Depan, Orasi Pengukuhan Jabatan Guru Besar Tetap dalam Ilmu Pendidikan Sejarah pada FKIP UNUD. Singaraja: FKIP UNUD. 